\title{
DAC \& the Working Party of TC Joint Meeting on Aid for Trade
}

\section{I. 회의 개요}

DAC \& the Working Party of TC Joint Meeting on Aid for Trade 회의가 2012년 1월 23 일 $\mathrm{OECD}$ 본부에서 개최 됨.

\section{II. 주요내용}

- (무역인프라 필요성) 개발을 위한 무역인프라 구축 필요성에 대해 G20, WTO, OECD 등 이 인식을 같이 하고 있으며 Aid for Trade 논의를 투자재원, 성과평가, 녹색성장 연계, 민간투자 촉진 등으로 확대

- (실효적 평가 접근) Aid for Trade의 실질적 성과 평가를 위해서는 세분화된 목표지수의 개발이 필요하며, 개도국 현장과 직결된 지표의 개발, 지역의 평가참여가 바람직

- (녹색성장 연계) 교통, 에너지 등 인프라 구축시에도 환경이슈와 연계한 무역환경 조성 필 요성에 대해 이해 확산

- (인프라구축 MDGs 달성에 기여) 인프라 구축을 통한 경제성장이 결과적으로 사회분야 투 자확대로 이어져 보건, 교육 및 여성의 인권신장에 기여

\section{III. 관찰 및 평가/건의}

- 서울 G20정상회의에서의 인프라구축 필요성 강조, 부산총회를 통한 개발효과성으로서 전 환을 계기로 인프라 구축과 법 · 제도적 투자환경 조성을 포함하는 Aid for Trade의 중요 성이 크게 부각

- 특히, 아프리카의 무역인프라 구축을 위한 ODA 지원확대와 민간투자 촉진 등 양적 확대 에 대한 요구가 증대되는 가운데, 민간참여 활성화를 위해서는 사전적으로 Enabling Environment 조성이 강조됨

- 과거 우리나라의 무역인프라 구축 사례, 관련정책 및 법제도 정비 등에 관한 개발경험 공 유(Knowledge Sharing)와 함께, 아프리카에 대한 우리나라 ODA 지원시 무역인프라 구 축을 주요 지원분야의 하나로 선정 필요 